\title{
The Othering of Majority and Minority Groups in Lessing and Ajidarma's Literary Works: A Postcolonial Analysis
}

\author{
Nandy Intan Kurnia ${ }^{a}$ \\ nandy intankurnia@uny.ac.id \\ Universitas Negeri Yogyakarta, Indonesia \\ Burhan Nurgiyantoro \\ burhan@uny.ac.id \\ Universitas Negeri Yogyakarta, Indonesia \\ Cindy Elsa Fitri \\ cindy.elsa@student.uny.ac.id \\ Universitas Negeri Yogyakarta, Indonesia
}

\begin{abstract}
A postcolonial reading of literary works remains relevant since the characters, stories and various issues related to the colonial domination discussed in literary texts may serve as a means for its readers to learn more about life under colonialism. This article examines how Doris Lessing, a British-Rhodesian author, and Seno Gumira Ajidarma, an Indonesian author, reveal the issue of discrimination of African native community and Indonesian-Chinese community because of the act of othering, respectively, from a postcolonial lens. This study used the critical content analysis technique on two literary works, namely Lessing's short story entitled "No Witchcraft for Sale" and Ajidarma's short story entitled "Clara", which is based on Spivak's theory of othering. Specific dialogues and utterances related to instances of discrimination were analyzed to uncover the othering of individuals, in this case, the main characters of the stories Lessing's short story captures the struggles encountered by the main character named Gideon, who belongs to the majority group, while Ajidarma's short story provides the portrayal of a young native Indonesian-Chinese descent who is a member of a minority group. The study found that Gideon faced racial discrimination and on the other hand, Clara faces racial and gender discrimination. By comparing two different literary works coming from two different cultures, nationalities, and historical backgrounds focusing on the issues of othering from a postcolonial perspective, this article can serve as a means for its readers to learn more about how the discrimination stemmed from different histories and how cultural background can create similar outcomes.
\end{abstract}

Keywords: discrimination; postcolonial; racial; gender; No Witchcraft for Sale; Clara

\section{INTRODUCTION}

Colonialism has been part of human civilization since the beginning of time. Up till the present, the problems between the colonizer and the colonized have not successfully been resolved as the colonized way of thinking is deeply rooted and colonial legacies remain strong. In many parts of the world, the former colonizers always see themselves as having a superior power, being more educated and civilized, and see the colonized as inferior, less educated and even uncivilized. The colonizers think that they have the right to exercise their power over the colonized (Said, 2003; Vichiensing, 2017). The binary opposition of "Us vs. Them" or "the Self and the Other" is one of the problems discussed under the topic of colonialism. These oppositions are constructed by the colonizer by creating a perception that there is a difference

${ }^{a}$ Main \& corresponding author 
between them, as the dominant group or known as "The Self" to the dominated one, "the Others" (Staszak, 2008).

Practices of othering can take shape in many forms of discrimination. Discrimination is one example of social phenomena which happens when a group of people is subordinated, marginalized, or oppressed. Similar to the case of the colonized, the discriminated group is often considered weak and inferior. To maintain this believe, hegemonic practices need to be established to create ideological apparatuses to support oppressive and discriminatory ideas. One of the apparatuses can be in the form of literature. Through literature, people instil ideas to be disseminated to the general public. With colonialism, this kind of literature can be produced in a mass to effectuate an extensive reach. However, this practice can also be applied in postcolonialism as a way to deconstruct colonialism beliefs. In fact, discussions on the countless instances of discrimination including the horrors and the wrongs of colonialism and its entailments can be found in various literary works and be regarded as a representation of reality. Literature offers a perspective on how the historical narratives and cultural background of a community can shape the forms of discrimination they face. It is particularly interesting to examine how discrimination which exists in various societies with different historical and cultural backgrounds can ultimately produce similar societal outcomes. Kazuo Ishiguro's Never Let Me Go is an example of literature that can be studied through the postcolonial point of view, especially in relation to the concept of 'othering', as it becomes obvious that this literary work can help its reader "to understand and aware of how negative consequences of the othering process affect undesirable treatments in the society as a whole" (Vichiensing, 2017, p.126). The practice of 'othering' is one example of the postcolonial problems between the colonizer and colonized. In this case, the colonizer marginalized the colonized to be the other (Vichiensing, 2017, p.126). However, discrimination is not as simple as 'the colonized' and 'the colonizer'. Discrimination can happen because of many bases, and some of them might not be as obvious as the others. In Never Let Me Go, Ishiguro explores the discrimination faced by human clones, a minority of the society as opposed to the actual humans as the majority group. The clones were not viewed to be real humans and their purpose in life is only as organ donors to the actual humans. Therefore, they face oppression and violation as the consequence of othering While it is science fiction, the insight of how discrimination might be systemic and is supported by the politics and government of a nation is a sophisticated point of view to ponder. Thus, the characters, story and various issues related to the practices of othering discussed in literary texts can serve as a medium for its readers to learn deeper about discriminations because of the act of othering. Moreover, in a study done by Chandran and Vengadasamy (2018), it is clearly seen that postcolonial way of thinking persists despite the seemingly modern way of thinking people collectively adopt today. They explain that the perception of the East as wild savages in need of the West's help still exists. In fact, the newer travel notes still adopt the point of views similar to the colonial era travel notes. Thus, by studying postcolonial works, people can deconstruct the reigning meaning built by the colonizer which is believed to be the truth and the right way, for history is written by winners. In this sense, literature can help open people's minds about the world and the way they see it because literary texts possess the power to influence the readers through the messages delivered between the lines.

This study analyses the discrimination portrayed in two short stories from different cultural backgrounds and histories through the lens of postcolonial study to demonstrate the universality of discrimination. The short stories are Doris Lessing's "No Witchcraft for Sale" and Seno Gumira Ajidarma's "Clara". Lessing's short story is about the life of Gideon, a native African cook, who lives with a White-settler missionary family, the Farquars. The conflict arises when Gideon reaches a crossroad between staying faithful to his cultural background or his employer's family. In contrast, Ajidarma's "Clara" is a story of a young Indonesian Chinese 
descendant who, despite having lived her whole life as an Indonesian and seen herself as one, is viewed as a non-native citizen by some Chinese descendant haters. Similar to Gideon, Clara experiences racism, particularly during the May 1998 riots in Indonesia. As widely known, Indonesia has a dark past concerning the issue of Chinese-Indonesian descendants. Some people cannot accept Chinese-Indonesian descendants as a part of the nation, to the point of labelling them as "non-native citizens". Thus, the positions of Gideon and Clara are not the same. Gideon is a part of the native African majority in a society dominated by the white minority, while Clara is an Indonesian of Chinese descent. The Chinese community is among the five larger minority ethnic groups in Indonesia. Both characters are discriminated by their society and must face problems caused by colonialism practices, in this case Gideon by the white settlers and Clara by the Chinese descendant haters, that have grown deep and deeply rooted in the history of the society where they live, and hence seemingly impossible to get rid of.

In the previous study by Rezkiyana (2017), it was found that the decision of Gideon as the main character to preserve his traditional culture can be seen as an egocentric action and as a support toward particularism. Moreover, he is considered as a close-minded man who find it difficult to accept new things. However, Gideon's decision can also be seen as his rejection toward the colonization of White settlers in the form of the discrimination of culture. In another study, Louw (2009) who studied some of Lessing's short stories on Africa, including "No Witchcraft for Sale", Louw discussed how Lessing tries to expose the threat of colonialism to Africa, especially to its tradition, in her stories.

On the other hand, a study by Rakhman (2014) of Ajidarma's "Clara" elaborated the different narratives surrounding the existence of the Chinese community by using postcolonialism through the rhetorical approach of tradition and development, the idea of universality and post-nation, and without neglecting the ambivalence presented in it. The study revealed how the current conceptions of the Indonesian Chinese community came to be, and how the racial issues surrounding the discussions have mostly political undertones of maintaining law and order in regard to the hegemony established in Indonesia. On the other hand, Resnitriwati (2014) exposed the way Ajidarma as a 'native' Indonesian wrote his honest feelings regarding the tragedy of 1998. Ajidarma's ideology is clearly shown in "Clara", in the way he understands where the natives' rage and prejudices came from, yet he condemns it because it goes against humanity, and ultimately none of the prejudices are proven to be true in the slightest. In his story, he explored a narrative of the tragedy surrounding the character of a Chinese woman's named Clara after she becomes a victim of a brutal rape incident in May 1998.

Previous studies on those two literary texts typically focus on the correlation between the writers, their short stories and the cultural and historical background in the perspectives of postcolonial studies. Little is known about the types of discrimination which happen due to the act of othering towards the majority and minority native groups. Although some of the previous studies use the same lens in examining both objects of the study, this study analyses both short stories from a postcolonial lens by examining the issues of discrimination suffered by the native majority group and by the minority group because of the act of othering. By aiming to explore two short stories with different backgrounds at the same time, this study becomes more insightful in presenting how discrimination can occur in different circumstances.

Since discrimination cannot be separated from humanity and culture, it is interesting to discuss in an era when discrimination and lack of humanity still exist almost in every part of the world. Thus, this study aims to investigate and explore further the issue of discrimination caused by the act of othering which is faced by the native majority and minority groups as depicted by the main characters in Doris Lessing's "No Witchcraft for Sale" and Seno Gumira Ajidarma's "Clara". The research question is: What kind of discrimination experienced by the 
main characters of Doris Lessing's "No Witchcraft for Sale" and Seno Gumira Ajidarma's "Clara" as native majority and minority groups because of the act of othering?

\section{POSTCOLONIALISM AND THE CONCEPT OF "OTHERING"}

Dobie (2012) defines colonialism as the oppression of one group of people towards another in terms of physical domination. However, in some cases, it also involves several other types of domination in economic, political, and cultural senses. Postcolonialism then develops as a reaction towards those kinds of dominations. It emerges to deal with the colonization effects "on cultures and societies" (Ashcroft, Griffiths \& Tiffin, 2007, p.168). In short, the term postcolonial refers to the effort to create new policies for a nation in terms of economic, political and social development to break free from the remaining systems made by the colonizer. Moreover, it consists of some actions, such as the act of reconstructing the cultures and folkloric forms of the native, and the act of rewriting the histories with the newest forms of narrative (Sharma, 2016).

Said (1978) first coined the term 'orientalism' to explain the concept in which the West's many assumptions and depictions of the East or the Orient are mostly degrading to ensure the West hegemony and power. Bhabha (1994) stated that there is a 'fixity' in the constructions of otherness, which means that there are fixed stereotypes used to other certain groups.

On the other hand, the concept of othering was first introduced by Spivak, which refers to the different ways in which colonial discourse generates its subject matters. It is "a dialectical process because the colonizing Other is established at the same time as its colonized others are produced as subjects" (Ashcroft, Griffiths \& Tiffin, 2007, p. 168). Spivak (1985) believed there are three determinations in the process of othering which include race, gender, and class. Therefore, this term can be seen as a result of the interaction between a group of people who have power and aim to exercise it toward another group of people whom they consider as powerless based on the fixed determinations. In fact, the party who holds the power will emphasize on "their own power, will, and value" (Mushtaq, 2010, p.25), hence using othering as a tool to oppress the inferior. Vichiensing (2017) adds that othering can happen in the form of exclusion and discrimination.

In the process of othering, many kinds of discriminations are perpetuated because group-based difference is seen as threat. Thus, because of self-protective motivation, the society which is composed by different groups need to come up with several solutions including segregation, secessionism, assimilation, inclusion and belongingness (Powell \& Menendian, 2018). Some of these solutions include insulating and treating the groups that are seen as a threat worse than the supposedly normal or the superior 'colonizer' and alienating them on the account of the irrational stereotypes made to ensure that 'the colonized' is viewed, both by 'the colonizer' and 'the colonized', to be beneath and weaker than 'the colonizer' (Giddens, et. al., 2009, p.334). In a sense, discrimination is done to ensure a certain power dynamic in the society where any kind of different human attributes is seen as a threat to one's existence. Thus, rather than intermingling or any other form of cultural assimilation, the solution lies in taking over the others instead. Traditionally as a species, this might be more advantageous in ensuring survival in the evolution race for differences, mostly in physique, are seen as a threat and should be avoided in case they possess any harm or diseases (Neuberg, Kenrick, \& Schaller, 2011). However, as a modern society, and modern humans, this is more harmful to human as a species as it does good since segregation undermines humanity in its core since the only race is the human race.

The focus of postcolonial literary criticism is the discussion of the portrayal of cultural differences in literary texts (Barry, 2002). It opens an opportunity to learn deeper about cross- 
cultural and multicultural communication and helps to introduce new perspectives, especially related to the perceptions of English exclusivity since postcolonial texts discuss the story of minority and its diversities, as well as transformation on the forms of cultural and lifestyles (Shands, 2008). Therefore, this kind of literature not only enables its readers to hear the voice of the minority and the unheard, but also helps them to understand more about postcolonialism and postcolonial literature as parts of colonial inheritances.

\section{METHOD}

This study adopts Spivak's (1985) point of view on the othering in which social practices are most often driven by race-class-gender determinations. Spivak stated that these determinations caused a group of people to look down on another and to assume more powerful, knowledgeable, and rightful position to certain human rights and commodities. The process of enforcing these ideas is multidimensional and involve several discriminations to completely others the other group. However, the study will only focus on race and gender discriminations presented in both stories by using critical content analysis.

There were several steps in conducting this research. Once the research question was formulated, data in the form of expressions, such as phrases, clauses, sentences and words in the objects of the study that were relevant to the discriminations caused by the act of othering were collected by thorough reading, re-reading, and note-taking. Specifically, the data were in the forms of sentences, dialogues, and utterances in Doris Lessing's "No Witchcraft for Sale" and Seno Gumira Ajidarma's "Clara" on the discrimination encountered by the main characters. The data were expected to give a clear explanation and description of the issues found in the short stories.

The main sources of the data were two short stories which share a similar topic: discrimination. The first was Doris Lessing's "No Witchcraft for Sale" which was published in 1951 in a collection of stories entitled This was the Old Chief's Country (Hagen, 2018), and the second one was Seno Gumira Ajidarma's "Clara". "Clara" was published in a collection of short stories entitled Iblis Tak Pernah Mati (The Devil Never Dies) (1999, 2001). "No Witchcraft for Sale" concerns a native African man working for a White-settler family. One day a venomous snake has spit onto the eyes of the family's only son. Gideon then finds a native plant, known to the Black natives as the antidote, to try to cure the son. After the son is no longer in danger of going blind, the family pressures Gideon to name and give the plant to White doctors in the name of science. However, Gideon refuses and is struggling to keep his knowledge of traditional medicine as a part of his cultural identity. On the other hand, "Clara" tells the story of a woman raped and shunned because of her ethnicity. Clara is a Chinese descent who just got back to Indonesia to find the country is in the middle of a riot. This riot is fuelled by racial sentiments against the Indonesian Chinese community nationwide. Clara tried to report the incident of the assault and rape but was met with condescension and more discriminations. Both the authors of these stories were in fact not a part of the oppressed group or community. However, through their writings, both of them reject the justification of discrimination to the weaker group.

In analysing and scrutinizing the discrimination in the treatments and sentiments toward the main characters of Doris Lessing's "No Witchcraft for Sale" and Seno Gumira Ajidarma's "Clara", the writers used the categorization of race and gender discrimination based on Spivak's theory to identify the process of othering in the story. The next step was interpreting the meaning of the data based on the forms of discrimination experienced by members of the majority and minority groups as depicted by the main characters in the short stories. 
TABLE 1. Analytical Construct

\begin{tabular}{|c|c|c|c|c|}
\hline No. & Category & Subcategory & Description & Indicators \\
\hline 1. & $\begin{array}{l}\text { Discrimination experienced by } \\
\text { the native majority and native } \\
\text { minority in the short stories. }\end{array}$ & $\begin{array}{c}\text { Racial } \\
\text { Discrimination } \\
\text { Gender } \\
\text { Discrimination }\end{array}$ & $\begin{array}{l}\text { Discrimination } \\
\text { related to race, } \\
\text { religion, or culture. } \\
\text { Discrimination, for } \\
\text { example to women. } \\
\text { Women are } \\
\text { regarded as inferior } \\
\text { to men in } \\
\text { patriarchal society } \\
\text { or family. }\end{array}$ & $\begin{array}{l}\text { Abuse towards a } \\
\text { person or a group } \\
\text { with different race } \\
\text { Treating a } \\
\text { particular gender or } \\
\text { one's identity as } \\
\text { inferior, and } \\
\text { deprive them of } \\
\text { some rights }\end{array}$ \\
\hline
\end{tabular}

The analytical construct based on Spivak's theory on the othering as used in the study is depicted above. The writers focused their attention on the category and subcategory to sort out the data and analyse the two stories by focusing on the indicators stated in Table 1. The indicators assist the writers in classifying whether the data classified as racial or gender discrimination caused by the act of othering.

\section{FINDINGS}

This study describes the forms of discrimination experienced by the main characters of Doris Lessing's "No Witchcraft for Sale" and Seno Gumira Ajidarma's "Clara". After scrutinizing both short stories by following the guidelines in the analytical construct, several discriminations because of the act of othering can be found throughout both short stories.

Based on the reading, both the main characters of Lessing's "No Witchcraft for Sale" and Ajidarma's "Clara" experience many difficulties because of their background. Their lives are full of ups and downs because of the terrible treatments from the society. There are two kinds of discrimination that they face; namely racism and gender discrimination.

\section{RACIAL DISCRIMINATION}

This study reveals that racial discrimination is one of the challenges frequently encountered by the main characters of Lessing's "No Witchcraft for Sale" and Ajidarma's "Clara". Several data imply the racism attacks are directed to them because of their background. The first datum is about the racial discrimination faced by the native majority group as seen in Lessing's "No Witchcraft for Sale":

Gideon's youngest son, who was now a herdsboy, came especially up from the compound to see the scooter. He was afraid to come near it, but Teddy showed off in front of him. "Piccanin," shouted Teddy, "get out of my way!" And he raced in circles around the black child until he was frightened, and fled back to the bush.

"Why did you frighten him?" asked Gideon, gravely reproachful.

Teddy said defiantly: "He's only a black boy," and laughed. Then, when Gideon turned away from him without speaking. (Lessing, 1951, p. 1).

As previously discussed, Gideon is a native African man who works at the farm in Africa which belongs to a white-settler missionary family, known as the Farquars. At first, they can build a good relationship since as a worker Gideon is treated equally. He feels at home working in the house of the Farquars and even feels as if he belongs to this family. However, the situation starts to shift when the Farquars have their one and only son. This is Gideon's first encounter with discrimination against his race in the story. As seen from the above quotation, 
Teddy, Gideon's beloved little master, calls Gideon's son as "Piccanin". This word, also known as "Piccaninny", is an offensive word which means a small (usually black) child (Oxford Learner's Dictionaries).

Moreover, Teddy shouts rudely by saying, "get out of my way!" to indicate that Gideon's son has interrupted his excitement in speeding with his new scooter. His racist attacks toward the little black boy do not stop right there since he responds to Gideon's question of why he makes the little black boy afraid by degrading him, "He's only a black boy". The word "only" can be seen as an indication that Teddy considers the little black boy as having lower social status than him and does not deserve to be treated with respect. Although Teddy's racist words are not directly directed at him, Gideon cannot say a single word since those words are thrown rudely to his son. He cannot afford to talk back since not only due to his position as an ordinary servant, but also because he believes what Teddy said to be true as he is conditioned to view himself as lower than the White Farquars. While being the ethnic majority of his land, Gideon is powerless in facing the prevailing racist ideology the White adopted to justify their acts of slavery and discriminations. The Whites with their more "advanced" sciences and ideology dictate how others should live to benefit the Whites. Even through theology, the Whites tried to spread the idea that their superiority is God's Will (Storey, 2018).

Another racism attack faced by Gideon emerges when he refuses to tell his secret in curing Teddy's eyes of the tree snake's poison, not even to "his former friends", the Farquars. This incident makes the Farquars see Gideon differently:

He was rude and stubborn. The Farquars could hardly recognize their gentle, lovable old servant in this ignorant, perversely obstinate African, standing there in front of them with lowered eyes, his hands twitching his cook's apron, repeating over and over whichever one of the stupid refusals that first entered his head.

Just because Gideon refuses to let them know about the secret medicine that he uses to treat Teddy, the Farquars start to see him as a rude, stubborn, ignorant and irrational —all of which are the stereotypes of the African man. Seeing how they make a distance by highlighting his background as an African man, Gideon responds to his master by lowering his eyes. It is to show that he wants to make a distance toward them too. Thus, their close relationship seems to turn to an end.

The narrator uses the word "African" to emphasise the description of Gideon's attitude in responding to the request of revealing the secret of his magical medicine, which the Farquars views negatively. They never ask Gideon the reason he keeps it as a secret, and they do not bother to contemplate about it. They keep on insisting to learn the secret potion's recipe by forcing Gideon to say the truth. It shows that the Farquars, as the representation of the West, see Gideon as an inferior who must obey their instruction and submit to them because they supposedly know better. However, Gideon is a man with strong self-integrity and he is determined to keep the medicinal plant a secret. Thus, up to the end of the story, no one knows about his magical medicine.

An example of racial discrimination can also be found in Ajidarma's "Clara". As an Indonesian native minority, she is viewed as an outsider by some people who hate her ethnic background.

Plak! Saya ditampar. Bibir saya perih. Barangkali pecah.

"Jawab! Pernah kan? Cina-cina kan tidak punya agama!" Saya tidak perlu menjawab.

Bug! Saya ditempeleng sampai jatuh. (Ajidarma, p. 3).

Slap! I was slapped. My lips sting. Maybe ripped.

"Answer me! You've done it, right? Chinese have no religion!" I didn't need to answer.

Thud! I was smacked till I fell down. (Ajidarma, p. 3). 
Clara, as a young Indonesian of Chinese descent, must face racism from the crowd just because she belongs to a minority group of the country. She is accused as an atheist since the accuser believed that all Chinese ethnic groups are atheists. This belief, which stems from the propaganda surrounding the notorious PKI-massacre between 1965-1966, still persists in Present-Indonesia that even the mainstream newspaper such as Republika has several questionable wordings in their news articles regarding China and CPC - the latter refers to a party which requires its members not to have a religion and the former is a country which has freedom of religion stated in its constitution (Basuki, 2018).

In another datum, Clara's eyes become the reason she is in danger not of only racist words but also violence:

\begin{abstract}
"Sialan! Mata lu sipit begitu ngaku-ngaku orang Indonesia!" Pipi saya menempel di permukaan bergurat jalan tol. Saya melihat kaki-kaki lusuh dan berdaki yang mengenakan sandal jepit, sebagian tidak beralas kaki, hanya satu yang memakai sepatu. Kaki-kaki mereka berdaki dan penuh dengan lumpur yang sudah mengering. (Ajidarma, p. 3).
\end{abstract}

"Bullshit! With those slanted eyes, you're saying you're an Indonesian?!” My cheeks stuck to the scratched surface of the road. I saw shabby and filthy feet wearing sandals, some were barefoot, only one wore shoes. Those feet are filthy with dried mud. (Ajidarma, p. 3).

Clara's attacker offensively shouted at her that she is not an Indonesian because she has slanted-eyes which is identical with the physical appearance of Chinese or Chinese descendant. The words used by the attacker shown an evidence of racial hatred. The root of the racial hatred can be traced back to four hundred years ago when VOC started to use its devide et impera (divide and rule) tactic toward the Chinese and the other ethnicities in Indonesia. At that time, VOC purposely gave privileges to the Chinese merchants to make the native merchants feel unjust over the situations and grow distaste for the Chinese merchants. Moreover, several ancient Javanese kingdoms were employing Chinese ethnics as tax officers and thus, cementing the image of the Chinese ethnics as greedy and demanding. The same monarchies also took part in several massacres of Chinese ethnics. Adding the fact that the New Order of the Indonesian government did the same with the notion that Indonesian Chinese ethnic carried the same communist ideologies as the CPC solely for sharing the same ethnicity, it is not farfetched to say that Chinese ethnics in Indonesia have always lived in fear just because their physical appearance denotes certain stereotypes, which most of the time is false (Dhani, 2016).

By tracing the history of white supremacy in colonial Indonesia, one will understand that the reason the Chinese ethnics were put above the Javanese or other Indonesian ethnicities, right below the White colonist was simply because of their lighter skin. This discourse was reversed after the Indonesian Independence in which Chinese-Indonesians are considered as the second-class citizens that are below "the more native" ethnic groups. The Chinese ethnics in Indonesia are put in a compromising situation most of the time. On one hand, some of them do have the privileges or manners akin to the stereotype. On the other hand, some of them, perhaps most of them, do not and yet still have to suffer the hatred resulting in discrimination and racism. This can be seen during the period of the New Order where upper-class Chinese ethnics was able to enjoy the corrupt systems and money (Sarwoto, 2020, p.202).

\title{
GENDER DISCRIMINATION
}

Racism does not always affect men in the same way as women. In some cases, women can face multiple discriminations, not only based on race but also gender, social class, or any other status. In the case of Ajidarma's short story, the character Clara also experiences gender discrimination. Gender discrimination itself refers to any form of a discrepancy, segregation or restriction made based on sex which is meant to neglect and pay no recognition to a certain gender, "irrespective of their marital status, on the basis of equality of men and women, of 
human rights and fundamental freedoms in the political, economic, social, cultural, civil or any other field" (European Institute for Gender Equality, 2019). In fact, gender discrimination cannot be separated from the act of colonization, and the colonial power have had a huge impact on women's life. For example, "the incursion of the British colonists had a significant effect on existing power relationship in Nigeria" (Jaiyeola \& Isaac, 2020). In the case of gender discrimination faced by Clara, the main character of Lessing's short story, the discrimination can be seen when she is taken by an old woman to the police office. The police officer who acts as one of the story's narrators describes how he feels when he meets Clara for the first time:

\begin{abstract}
Di hadapanku duduk wanita itu. Rambutnya dicat merah. Coklat sebetulnya. Tapi orang-orang menyebutnya merah. Padahal merah punya arti lain bagiku. Sudah bertahun-tahun aku dicekoki pikiran bahwa orang-orang merah adalah orang-orang yang berbahaya.

Jadi, aku tidak perlu percaya kepada wanita ini, yang rambutnya sengaja dicat merah. Barangkali isi kepalanya juga merah. Barangkali hatinya juga merah. Siapa tahu? Aku tidak perlu percaya kepada kata- kata wanita ini, meski ceritanya sendiri dengan jujur kuakui lumayan mengharukan. (Ajidarma, p.1).
\end{abstract}

\begin{abstract}
That woman sat in front of me. Her hair was dyed red. Brown actually. But people call it red. And "red" has another meaning for me. For years I have been bombarded with the idea that red people are dangerous.

So I don't need to believe this woman, whose hair was deliberately dyed red. Maybe the inside of her head is also red. Her heart too. Who knows? I don't need to believe in the words of this woman, even though I admit her story is kind of touching. (Ajidarma, p.1).
\end{abstract}

Before Clara confesses, the officer already made his conclusion that he does not need to believe in her confession since she is Chinese and only a woman. The way he describes Clara's hair as "red" instead of "brown", the actual colour of Clara's hair, indicates Clara is being discriminated against as the officer stereotypes that all Chinese are communists. It is indicated by the use of the colour "red" which is commonly associated with the left-wing movement. Therefore, the officer is sure that he does not need to believe this "red-haired woman" and underestimates the truth in Clara's story. In this case, Clara is disadvantaged by her background, not only as a Chinese descendant but also as a woman. This case shows the intersectionality of gender and race. Pradhan-Malla (2003) explains that women who face discrimination based on both ethnicity/race and gender have a higher possibility to encounter violence.

Also, the fact that the Communist Party of China (CPC) has indeed become the sole control of the government of China (Britannica), has nothing to do with Clara's identity as an Indonesian despite her background as a Chinese descendant.

Saya hanya tahu bahasa Indonesia dan bahasa Inggris untuk urusan bisnis. Kata orang, bahasa Cina sangat kaya dalam hal menggambarkan perasaan, tapi saya tidak bisa bahasa Cina sama sekali dari dialek manapun, kecuali yang ada hubungannya dengan harga-harga. Saya cuma seorang wanita Cina yang lahir di Jakarta dan sejak kecil tenggelam dalam urusan dagang. Saya bukan ahli bahasa, bukan pula penyair. Saya tidak tahu apakah di dalam kamus besar Bahasa Indonesia ada kata yang bisa mengungkapkan rasa sakit, rasa terhina, rasa pahit, dan rasa terlecehkan yang dialami seorang wanita yang diperkosa bergiliran oleh banyak orang-karena dia seorang wanita Cina. (Ajidarma, p.5).

I only know Indonesian and English for business. People say the Chinese language has a great vocabulary for describing feelings, but I can't speak Chinese at all in any dialect, except for some words related to prices. I am only a Chinese woman who was born in Jakarta and only knew about dealing with business since childhood. I am not a linguist, nor a poet. I do not know whether there is a word in the great dictionary of the Indonesian language which can express the pain, shame, bitterness, and humiliation experienced by a woman who is raped in turn by many people - because she's a Chinese woman. (Ajidarma, p.5). 
Clara was born in Indonesia, she speaks Indonesian and English, and only understands the Chinese language related to prices. Therefore, it is unfair to treat her as if she was a Chinese native or carrief CPC's ideologies. Moreover, the above quotation can be seen as evidence of gender discrimination because Clara is being raped "because she is a Chinese woman." As stated by Pradhan-Malla (2003), women become the target of violence because they are "perceived as being part of an economically elite ethnic minority". She adds that "during the civil unrest in Indonesia in 1998, hundreds of ethnic Chinese women were specifically targeted for rape and sexual torture" and the Committee on the Elimination of Discrimination against Women has announced that all types of gender-based violence are classified as a type of discrimination. Clara being a Chinese ethnic and noticeably richer than her violators add to the aggression her rapists feel towards her.

Another datum related to this is seen when the narrator, the police officer, shows a disrespectful attitude towards "Clara" by refusing to believe in Clara's confession, just because of her ethnicity and her background as a woman:

"Sudah bertahun-tahun aku dicekoki pikiran bahwa orang-orang merah adalah orang-orang yang berbahaya. Jadi, aku tidak perlu percaya kepada wanita ini,” (Ajidarma, 1). Therefore, he stated, "Jangan terlalu mudah menyebarkan isyu diperkosa. Perkosaan itu paling sulit dibuktikan. Salah-salah kamu dianggap menyebarkan fitnah.”(Ajidarma, p.6).

"For years I have been bombarded with the idea that red people are dangerous. So I don't need to believe this woman," (Ajidarma, 1). "Don't throw the rape word around lightly. Rape is hard to prove. If you're not careful you might be accused of slander." (Ajidarma, p.6).

It means the officer's background as a majority of Indonesian natives who disapprove of the Chinese ethnics, worsened by the indoctrination that all Chinese are related to Communism, clashes with the background of Clara as a Chinese descendant. Hence it is difficult for the officer to be fair to Clara as he even considers her to be merely spreading baseless rumors. Despite being a victim, Clara is considered to be a bad person. It does not occur to the officer that Clara is another human being who can experience violence or discrimination because in his mind Chinese Indonesian descendants are put in a high pedestal in society, while in reality, it is the opposite.

This description can be connected to the history of Indonesia during Suharto's regime. At that time, a small number of Chinese ethnics enjoyed various kinds of investment facilities, which then make them become incredibly rich. In the end, this small number of people was considered as the representation of all Chinese. For this reason, when the fall of Suharto happened in 1998, riots arose in many parts of Indonesia aiming the Chinese community as a target of hatred (Dhani, 2016). Thus, Clara can be seen as a victim of not only of racism but also of gender discrimination, and her position is similar to that of the human clones in Ishiguro's Never Let Me Go, who are discriminated "as inferior, less human, and devalued" (Vichiensing, 2017, p. 131).

\section{DISCUSSION}

\section{DISCRIMINATIONS EXPERIENCED BY THE MAIN CHARACTERS OF LESSING'S "NO WITCHCRAFT FOR SALE” AND AJIDARMA'S “CLARA”}

There are a lot of pre-existing narratives surrounding the others made by the self, the Eastern by the Western, the colonialized by the colonizer, the non-native by the native, or the less powerful by the more powerful. All these narratives influence how these people act in societies where two or more cultures are intermingled. This culture-based differentiation is then linked to race because of the differences in the self's culture and the others', and that one of the many ways to tell where one belongs to in a societal group is through how they look. 
Discrimination in terms of racial injustices, or racism, and gender discrimination then became one of the most common struggles Gideon and Clara must face each day for their looks are different than the supposedly superior groups of their societies. Gideon as a Black man is viewed as lowly, unintelligent and savage, only suitable to work under the White. On the other hand, as a Chinese descent, not only is Clara stereotyped as being greedy and immoral, she is also being objectified as her racial features are considered to be the beauty standards at the time. Thus, the discriminations which happen to Gideon and Clara can be categorized as one of the forms of the act of othering as explained by Vichiensing (2017).

This struggle is one of the hardest to overcome for they cannot hide their physical qualities. They are immediately subjected to injustices that are deeply rooted in the society that it becomes systemic, as clearly seen in the way the officer behaves and treats Clara. The officer, who is supposed to be neutral and law-enforcing, even participates in racism himself. In Gideon's case, the Farquars, a missionary family, is enforcing racist treatments towards Black African people even though they are supposed to be the messengers of God. Storey (2018) explains that all of the notions of racism perpetuated by White people are historically made to justify the colonialism and slavery White people do to their colonies. They adopt the notion that White people are intellectually superior and thus fair in judging the capacities of the colonized. Some of the "scientific" writings regarding Black people were even written with nuances akin to writings written about foreign animal species. Moreover, white people even involve religions in their discriminatory acts by justifying and stating that God willed the world to be like so and that White people are inherently, divinely superior.

The racial and gender discrimination then make the life of some people harder since they have to struggle more. Gideon is forced to only mingle with his Black peers and to accept whatever decision his masters forced upon him, which later he tries to resist. Meanwhile, it can be inferred that Chinese Indonesians in "Clara", no matter how rich, will be constantly opposed to occupy a political position, which is a position capable of decision-making for the society. Both marginalized groups ultimately hold no power or say regarding the decision-making in their own society and are forced to accept whatever the oppressors want to impose in said society, including discriminative regulations and norms.

All of the above then contribute to the making of cultural classes in discriminative societies. They establish a society in which discrimination is a part of the system, and in turn, normalized. Because the oppressors are the ones with power and not in any way underprivileged, they see nothing wrong with such a way of life. On the other hand, the oppressed may feel that they have no way to change such a long-standing system and are forced to accept a disadvantaged role and life in said society.

\section{CONCLUSION}

This study is a complement to previous studies on the two short stories, namely Doris Lessing's short story entitled "No Witchcraft for Sale" and Seno Gumira Ajidarma's short story entitled "Clara". The findings indicate that the postcolonial study of Lessing's and Ajidarma's main characters is able to uncover the discrimination towards the native majority and native minority group caused by the act of othering, and how the discrimination stemmed from different histories and cultural background can create similar outcomes. "No Witchcraft for Sale" portrayed a racial discrimination faced by Gideon, a Black man from the native majority in colonial Africa. On the other hand, "Clara" not only depicts racial discrimination but also discrimination based on gender.

Thus, Lessing's "No Witcheraft for Sale" and Ajidarma's "Clara" are literary works that display the experiences of both minority and majority groups which must experience different, derogatory treatments because they look different from their oppressors. Also, as the 
authors are not part of the oppressed group, this shows that the majority can reject the notion of hegemony perpetrated by their own group. In this regard, reading these two short stories helps readers to have more awareness in understanding the struggles, experiences, and effects of racism towards groups in society regardless of their size. It also highlights the importance of studying today's issues further through the lens of postcolonialism.

\section{REFERENCES}

Ajidarma, S. G. "Clara". Retrieved November 3, 2019 from https://terokata.wordpress.com/2014/05/12/clara -atawa-wanita-yang-diperkosa/

Ashcroft, B., Griffiths, G., 7 Tiffin, H. (2007). Post-colonial studies: The Key concepts. ${ }^{\text {nd }}$ Ed. Barry, P. (2002). Beginning Theory: An Introduction to Literary and Cultural Theory. 2nd ed. Manchester: Manchester University Press.

Basuki, N. (2018). "Benarkah Partai Komunis Cina Paksakan Ateisme". historia.id. Retrieved December 18, 2019 from https://historia.id/agama/articles/benarkah-partai-komuniscina-paksakan-ateisme-61JAE

Bhabha, H. K. (1994). The Location of Culture. London: Routledge.

Britannica. Retrieved July 1, 2020 from https:/www.britannica.com/

Chandran, G., \& Vengadasamy, R. (2018). Colonialist Narrative in a Post-Colonial Era Travel Writing, Into the Heart of Borneo. GEMA Online ${ }^{\circledR}$ Journal of Language Studies. Vol. 18(4). Retrieved from: http://doi.org/10.17576/gema-2018-1804-02

Dhani, A., (September 1st, 2016). Sejarah Kebencian Terhadap Etnis Tionghoa, Tirto.id. Retrieved December 18, 2019 from https://tirto.id/sejarah-kebencian-terhadap-etnistionghoa-bFLp

Dobie, A. B. (2012). Theory into practice: an introduction to literary criticism. 3rd ed. Boston: Wadsworth, Cengage Learning.

Giddens, A., Duneier, M., Appelbaum, R. P., Carr, D. (2009). Intrduction to Sociology. New York: W. W. Norton \& Co.

Hagen, A. S. (2018). D. Lessing: "No Witchcraft for Sale". Retrieved January 8, 2020 from https://ndla.no/article/8471

Jaiyeola, E. O. \& Issac, A. (2020). Patriarcy and colonization: The "Brooder House" for gender inequality in Nigeria. Journal on Women and Gender, Vol. 10, 3-22.

Lessing, D. "No witchcraft for sale". Retrieved October 23, 2019 from https://www.polk.k12.ga.us/userfiles/826/Classes/182955/No\%20 Witchcraft $\% 20$ for $\%$ 20Sale.pdf

Louw, P. (2009). The vexed "colour problem": Doris lessing and the "african renaissance". Inkanyiso, Jnl Hum \& Soc Sci, Vol. 1(1).

Mushtaq, H. (2010). Othering, stereotyping and hybridity in fiction: a Postcolonial analysis of Conrad's Hear of Darkness (1899) and Coetzee's Waiting for the Barbarians (1980). Journal of Language \& Literature (3), 25-30.

Neuberg, S. L., Kenrick, D. T., \& Schaller, M. (2011). "Human Threat Management Systems: Self-Protection and Disease Avoidance". Neuroscience and Biobehavioral Reviews 35 (4), 1042-1051.

Oxford learner's dictionaries. Retrieved from https://www.oxfordlearners dictionaries.com/definition/english/piccaninny?q=piccaninny

Powell, J. A., \& Menendian, S. (2018). The Problem of Othering: Towards Inclusiveness and Belonging. Retrieved February 05, 2021, from https://www.otheringandbelonging.org/ the-problem-of-othering/ 
Pradhan-Malla, S. (2005). Racism and gender. In Dimensions of Racism. Proceedings of a Workshop to commemorate the end of the United Nations Third Decade to Combat Racism and Racial Discrimination. New York and Geneva: United Nation.

Rakhman, A. K. (2014). Ambivalensi nasionalisme dalam cerpen "Clara atawa wanita yang diperkosa" karya Seno Gumira Ajidarma: Kajian poskolonial. Jurnal Poetika, Vol. 2(2).

Resnitriwati, C. (2014). "Clara" Karya Seno Gumira Ajidarma Dalam Kajian Stilistika. Humanika, Vol. 19(1).

Rezkiyana, P. A. (2017). Deconstruction Analysis: The Ideas of Keeping Tradition in "No Witchcraft for Sale" by Doris Lessing. Advances in Social Science, Education and Humanities Research (ASSEHR), Vol. 148. Sixth International Conference on Language and Arts (ICLA). Atlantis Press.

Said, E. W. (1978). Orientalism. Harmondsworth: Penguin.

Sarwoto, P. (2020). "Reimagining The Fluid Categorization of The Communist, Chinese, and Jews in Umar Kayam's Fiction". Kritika Kultura 35: 194-212

Shands, K. W. (2008). Neither east nor west: Postcolonial essays on literature, culture, and religion. Elanders.

Sharma, A. (2016). The emergence of postcolonialism: A historical aspect. BEST: International Journal of Humanities, Arts, Medicine and Sciences, Vol. 4(3), pp. 4952.

Spivak, G. C. (1985). The Rani of Sirmur: an essay in reading the archives. History and Theory, 24(3): 247-272

Staszak, J.F. (2008). Other/Otherness. International Encyclopedia of Human Geography. Elsevier.

Storey, J. (2018). An introduction to cultural theory and popular culture (8th ed.). New York: Routledge.

Vichiensing, M. (2017). The othering in Kazuo Ishiguro's never let me go. Advances in language and literary studies. Australian International Academic Centre PTY.LTD. Retrieved December 12, 2019 from http://dx.doi.org/10.7575/aiac.alls.v.8n.4p.126

\section{ABOUT THE AUTHORS}

Nandy Intan Kurnia is an English literature lecturer and a postgraduate student of Language Educational Science at Universitas Negeri Yogyakarta, Indonesia. Her research interests are predominantly in the areas of English literature, Children's literature, Feminism, and English language education.

Burhan Nurgiyantoro is a Professor in Indonesian language and literature at Universitas Negeri Yogyakarta, Indonesia. His main teaching and research interests include language, literature, children's literature, evaluation, education and character education.

Cindy Elsa Fitri is an alumnus of English literature study program who currently does freelance writing and translating. She is interested in the world of creative writing, humanities and English literary study. 